\title{
The Effect of Role-Play and Simulation Approach on Enhancing ESL Oral Communication Skills
}

\section{Nurul Ajleaa binti Abdul Rahman ${ }^{1 *} \&$ Nooreiny Maarof ${ }^{2}$}

\footnotetext{
* Correspondence:

ajleaa.nurul@gmail.com

${ }^{1}$ General Studies Department,

Politeknik Sultan Salahuddin Abdul

Aziz Shah, Selangor, Malaysia

${ }^{2}$ Faculty of Education, Universiti

Kebangsaan Malaysia, Selangor,

Malaysia
}

Received: 12 March 2018

Accepted: 28 May 2018

Published online: 20 September 2018

\begin{abstract}
This study investigated the effect of role-play and simulation approach on Malaysian Polytechnic engineering students' ESL oral communication skills. In addition, the study examined the students' perceptions of the effect of the role-play and simulation on their oral communication skills. A mixed method design was employed, using both quantitative and qualitative data collection approaches. The quantitative data were collected from the quasiexperimental study $(n=100)$. The data were collected using a set of questionnaire, a pre and post-test. The data from the questionnaires were analysed using descriptive statistics (percentages and means). The results showed that there was a significant difference between the pre-test and the post-test scores of the role-play and simulation group compared to the traditional group. The findings indicated that the students in the role-play and simulation group had performed better in the post-test compared to the pretest after the exposure to the role-play and simulation approach in the ESL oral communication skills classes. An implication of the study is that roleplay and simulation approach can serve as a possible strategy to improve on their ESL oral communication skills.
\end{abstract}

Keywords: role-play, simulation, communicative approach, ESL, oral communication skills 


\section{Introduction}

In today's business and education world, communication skills are considered to be one of the important skills that undergraduate students need to possess in order to secure job opportunities in government and commercial industries. Most employers are concerned about employees' ability to communicate in group discussions, to conduct meetings in public speaking and for personal purposes. More than 400,000 Malaysian undergraduates are jobless with one reason which is incompetent in the English language and lack of communication skills (Karim, 2016).

Lack of communication skills is one of the reasons why employers are reluctant to hire job applicants. One of the difficulties which prevent learners from learning to speak in English is due to apprehension (Fung \& Min, 2016). The acquisition of English as a Second Language (ESL) especially speaking skills still remains critical despite numerous actions taken to improve the use of English (Fung \& Min, 2016; Yunus \& Kaur, 2014). They are anxious and lack confidence when it comes to speak in English for the fear of making mistakes (Fung \& Min, 2016). Lack of communication skills is often due to fear, anxiety feelings, and weak confidence exists in situations when people communicate with each other. There is a need to find a means that would overcome this fear and develop learners' confidence to use the language in a fun and motivating ways (Toledo \& Hoit, 2016).

\subsection{Statement of the Problem}

Communication skills are considered to be one of the critical skills that undergraduate students need to develop. Anxiety and fear affect a person's ability to communicate well in social and work situations such as in meetings, in public speaking, and in interpersonal and group discussions. These feelings affect a person's intention and attitude towards involvement in communication situations. The students feel embarrassed to speak in front of their friends and lecturers because they afraid of making mistakes.

Apprehension and lack of self-confidence are some of the causes which hinder the learners from speaking in the target language (Fung \& Min, 2016). There are several reasons which cause learners to become apprehensive and less motivated to speak in English. Firstly, both lecturers and students in Malaysia are exam-oriented due to the education system which emphasizes examination (Christopher, 2016; Lee, 2016). According to Lee (2016), Malaysian education system lacks creativity which causes students to feel bored and dreadful.

It is hoped that this research could help students to enhance their oral communication skills and thus eventually provide instructors teaching English with guidelines and activities that could assist ESL students in improving their confidence to communicate in the English language. The overall purpose of this study is to examine the effect of role-play and simulation approach among engineering students at Polytechnics. In particular, the study investigates the students' perceptions towards the use of this approach and benefits of role-play and simulation to the students in enhancing their ESL oral communication skills.

\subsection{Objectives of the Study}

The objectives of the study are:

1. To investigate the effect of role-play and simulation approach on Malaysian Polytechnic engineering students' ESL oral communication skills.

2. To examine the students' perceptions towards the use of the role-play and simulation approach on their oral communication skills.

3. To investigate the benefits of using role-play and simulation to the students in enhancing their ESL oral communication skills.

\subsection{Research Questions}

The research questions of the study are as follows:

1. What is the effect of role-play and simulation approach on Malaysian Polytechnic engineering students' ESL oral communication skills?

2. What are the students' perceptions towards the use of the role-play and simulation approach on their oral communication skills? 
3. What are the benefits of using role-play and simulation to the students in enhancing their ESL oral communication skills?

\subsection{Significance of the Study}

The study is important in identifying role-play and simulation approach which can help to enhance ESL oral communication skills among engineering students in polytechnic. The students have no confidence to speak in English and prefer to communicate daily in their mother tongue and they are reluctant to use English for fear that they will receive unfavourable responses from people surrounding them (Rahman \& Maarof, 2015). Abu Zahra and Farrah (2016) discusses that the majority of the students do not have much practice and they do not improve their skill of learning the language. Therefore, when the students have to do speaking activities at the tertiary level, they would assume it as a complicated task. The limited hours of instructions also worsen the situation as the students do not have enough time to do speaking practice (Abu Zahra \& Farrah, 2016). It is hoped that the findings of the study could contribute to a better understanding of the implementation of effective communicative approach to build up students' confidence in ESL oral communication skills. Specifically, this study explores the benefits of role-play and simulation approach as one of the best and effective approaches in enhancing ESL oral communication skills among students.

\section{Literature Review}

Communicative approach is considered as the most effective theoretical model in English language teaching since the early 1970s. The underlying concept of this approach is that language carries not only functional meaning, but also social meaning. Thus, it is not only important to learn the linguistic forms but also to understand their potential communicative functions and social meanings. Learners should be able to relate linguistic forms to appropriate nonlinguistic knowledge in order to interpret the specific functional meaning intended by the speaker (Littlewood, 2007). One of the most common features of communicative language teaching is that it pays systematic attention to functional as well as structural aspects of language, combining these units into a more fully communicative view (Littlewood, 2007).

Communication can be defined as the process of transmitting information and common understanding from one person to another (Keyton, 2011). The definition underscores the fact that unless a common understanding results from the exchange of information, there is no communication. According to Mahdi (2015), the greater part of the students longing to figure out how to communicate in English well and are willing to interface with others in oral English language classrooms. Nonetheless, because of different reasons, for example, absence of practice, low English capability, absence of certainty, tension, timidity, identity, trepidation of losing face, and apprehension of committing errors, more than $66 \%$ of the students stay hesitant to react to the instructor and stay silent until singled out to answer questions.

With the rising value of communication in the modern era, people tend to focus on the ability to speak a second language fluently instead of just reading or writing it. Yet, fluency in a second language requires more than learning grammatical and semantic rules. This is especially difficult for ESL learners because of the minimal use of the target language and contact with native speakers. Consequently, ESL learners, generally, are relatively poor at spoken English, in particular regarding fluency and control of idiomatic expressions. However, in practice, it is too often assumed that learner's communicative proficiency can be developed simply by assigning students topics to discuss and encouraging them to participate in various speaking tasks (Mahdi, 2014).

There are many past researches carried out, which revealed that anxiety is the cause for ESL learners to avoid speaking in English. The study carried out by Christopher (2016) identified the same problem where 15 out of 30 year 5 primary pupils admitted that the anxiety of being criticised by others stopped them from speaking in English. In addition, this was also evident in the study carried out by Fung and Min (2016) which shows most of the learners $(66.6 \%)$ often experience the feeling of apprehension and uncomfortable especially during oral communication skills presentation in front of the class.

\subsection{Role-play and Simulation}

Acting in language learning is valuable because we are all, perhaps, actors when speaking another language. Acting accustoms students to perform in front of others, which is what they have to do outside the classroom. Role-play is a well-known strategy that helps students to familiarize themselves with new social environments. Shankar, Piryani, Singh, and Karki indicated that "role-play early in the course can expose students to different situations they are likely 
to face in their future career" (Shankar et al., 2012). The role-play activity helps learners to build their creativity. Roleplay is a strategy in which students are required to act specific roles through saying, doing, and sharing (Altun, 2015). Meanwhile, Qing (2011) stated that role-play is defined as the projection in real life situations with social activities. The use of role-play activities develops communication skills and students are encouraged to master through conversational activities (Afdillah, 2015).

According to Krebt (2017), role play is to participate in simulated social situations that are intended to illustrate the roles and contexts that direct to the real life. Role play is an approach in facilitating learning proves to be effective in reaching learning outcomes in three major learning domains: affective, cognitive, and behavioural (Maier, 2002, Rao \& Stupans, 2012). Finally, role play engaged as a training approach that has the capacity to change behaviours and use only the best practices in the real world settings (Qing, 2011, Raja Hazirah Raja Sulaiman et al., 2017; Shangeetha \& Rajah Kumaran, 2017). Simulation is also a good activity because it helps learners to overcome the feeling of nervousness. It induces them to speak expressively in a situation, and thus makes them more aware of stress and intonation in speech. Role-play and simulation are forms of experiential learning (Russell \& Shepherd, 2010). Roleplay involves everyone, those in the audience want to see how their fellow students will perform, and thus become conscious that they too will soon be on 'stage' themselves.

Fear or anxiety in speaking can be related to such factors as a poor grasp of the target language, lack of practice, certain insecurities or a pre-programmed thought process. Among Malaysian students, anxiety can be attributed to one of the highest factors that dampens the success of student's second language acquisition (Mustapha, Ismail, Singh, \& Alias, 2010). It has also been recorded that students who are so fixated on their speaking anxiety, tend to spend most of their time focusing on that instead of the task at hand, resulting in a reduction in the retention of information and thus lowering their grades (Mustapha, Ismail, Singh \& Alias, 2010). The need to use the communicative approach in overcoming public speaking anxiety can be linked to studies that found students requesting for more exposure and practice in overcoming their communication apprehension (P'Rayan \& Shetty, 2008).

\section{Methodology}

\subsection{Research Design}

The quantitative research method has employed in this study which involved data collection via a questionnaire, experimental pre-test and post-test method. The main objective of this study is to investigate the effect of role-play and simulation approach in teaching oral communication skills. For quantitative data, the research intends to look at the effects of the role-play and simulation approach on ESL oral communication skills of the first year engineering students of Polytechnic.

\subsection{Population and Sampling Procedures}

The sample in the study comprises the first year engineering students in Selangor Polytechnic, enrolled in the compulsory core course Communicative English 1 (DUE 1012) for the experimental study. The students' ages are between 18 to 20 years old. The numbers of respondents are 100 students which are 50 students in role-play and simulation approach group and 50 students in the traditional activities group. It runs for one semester, comprising 14 weeks of lectures. The main objective of the course is to remedy the students' weaknesses in the use of English and raise their proficiency level. These students were chosen because they had been exposed to communication classes and were expected to graduate soon. Therefore, it was important to examine their levels of communication apprehension and to find out whether they possessed the necessary speaking skills. In addition, we sought to determine whether they were prepared to face the challenges of communicating with confidence after graduation.

The experimental pre-test and post-test study was conducted in Selangor Polytechnic. The number of study sample amounted to 100 male and female students distributed into two sections studying the engineering department who were chosen in an intentional manner. The researcher used the random allocation where used to allocate the experimental and control groups: an experimental section was subjected to role-play and simulation approach and a control section was taught by using the traditional method. This quasi experimental study followed a pre-test and posttest group design with a treatment phase lasting 14 weeks. The experimental group was taught by using role-play and simulation approach and the control group taught using the existing method of teaching. Immediately after the completion of the treatment for 14 weeks, the two classes were measured for their oral communication skills using the same tool. The pre-test and post-test scores were compared to see the difference in the level of oral communication skills of the sample. 
To achieve the prospective objectives from the study, the researcher prepared the study materials for the social studies course in a suitable method for the role-play and simulation approach. Next, the researcher verified the validity and reliability of the oral communication skill scale by the suitable methods. Two sections were allocated randomly into two groups: an (experimental) group which taught by the role-play and simulation approach, and a (control) group which taught by the traditional method.

\subsection{Instruments}

The NCA Speech Evaluation Form and Oral Presentation Rubrics adapted in this study were used to rate students' oral performance. The National Communication Association (NCA), USA has devised a set of speech evaluation forms to measure oral communication. The oral communication tests were rated using standard oral presentation measurement rubrics which had five components (content, organization, language, adaptation to audience and context and use of paralinguistic features). Each component is evaluated out of 5. Each of the two oral tests is evaluated out of 25 and the results are summed up to indicate achievements out of 50 points. The course lecturer was given the rubrics to evaluate students' oral presentation tasks in the classroom and the evaluation is made together with one of the researchers. The inter-rater reliability is 0.89 . It is also to guarantee reliability that the oral assessment is made twice and by two experts.

\subsection{Data Collection}

The data has been collected using a closed ended questionnaire which students have to complete individually. The purpose of the questionnaire is to reveal the level of oral communication skills students have ranging from low to moderately low, moderate to moderately high and high. This was measured using 24 items. The items were marked using a 5 point Likert-scale of (1) Strongly Agree, (2) Agree, (3) Undecided, (4) Disagree, and (5) Strongly Disagree. Lowest attainable score is 24 and highest is 120 (P'Rayan \& Shetty, 2008). The interview participants were selected from the first year engineering polytechnic students and also from experimental group that already have the treatment using role-play and simulation approach within 14 weeks.

\subsection{Data Analysis}

Data analysis will be conducted once all respondents have completed the questionnaire. Two groups of students which are experimental and control group filled up the questionnaire form. The Likert scale item has calculated the overall score from the NCA Speech Evaluation Form and collected as pre and post test scores. These analyses were intended to assess the general situation of first year engineering students regarding their level of English communication and the effectiveness of role-play and simulation approach in enhancing oral communication skills.

For the qualitative method, with the permission of the interviewees, each interview was recorded and all of the interviews were conducted by the researcher. At the beginning of each interview, the objective of the study was explained, the confidential nature of it was emphasized, and the anonymity of the interviewees was guaranteed. It was stressed that there was no compulsion to answer any question and that the interviewee could terminate the interview at any time if he/she so desired. The initial part of each interview was devoted to discuss the interviewee's family background, schooling, friends, and hobbies. When sufficient rapport had been established and the interviewee appeared sufficiently relaxed, the conversation then turned to the interviewee's experience and perception of OCA.

The interviews were conducted at the General Studies Department meeting room in Selangor Polytechnic. The interviewees were informed at the conclusion of the interview that the interview transcript would be sent to them so that it could be reviewed and they could make corrections if necessary or desired. Each interview took 45 minutes approximately and was subsequently transcribed. The data were then analyzed to uncover common themes. The outcomes of the 6 interviews were 6 stories, with many commonalities but also with some unique aspects which provide rich and interesting narratives.

\section{Findings}

Based on the findings, it was indicated that the students were enthusiastic about role-play and simulation activities because they never got bored and could practice speaking so many times. This approach also was different from other activities done in class. After the treatment within 14 weeks, they showed outstanding enhancement in their communication ability and they were able to speak confidently. Table 4.1 indicates the overall oral communication skills of the 100 students who completed the NCA Speech Evaluation Form in pre-test and post-test which are 50 students in role-play and simulation approach group and 50 students in the traditional activities group. 
The means and standard deviations of grades of engineering polytechnic students were calculated in both groups: The experimental group (which was subjected to the use of communicative activities) and the control group (which was subjected to the use of the traditional method) according to the communication apprehension scale and oral communication scores in the pre-test. Comparison of pre-test scores between the experimental and control group are discussed in this section.

Table 1. Result for the mean pre-test scores of the experimental and control group

\begin{tabular}{lllll}
\hline & Groups & Mean & $\begin{array}{c}\text { Std. } \\
\text { Deviation }\end{array}$ & $\mathrm{N}$ \\
\hline Pre-test & Experimental Test & 60.1600 & 5.62560 & 50 \\
Oral Communication & & & & \\
Skills Scores & Control Test & 60.8800 & 6.73595 & 50 \\
& Total & 60.5200 & 6.18483 & 100 \\
\hline
\end{tabular}

No significant difference was found between the means of the control and experimental groups in the pre-test based on Table 1. The purpose was to find out if the treatment (role-play and simulation approach) had produced any significant differences in the performance of the subjects. Therefore, it can be concluded that there is no significant difference among the groups.

Table 2. Result for the mean post-test scores of the experimental and control group

\begin{tabular}{lllll}
\hline & Groups & Mean & Std. Deviation & N \\
\hline & & & & \\
Post-test & Experimental Test & 85.0800 & 3.61877 & 50 \\
Oral Communication & & & & \\
Skills Scores & & & \\
& Control Test & 62.3800 & 8.38826 & 50 \\
& Total & 73.7300 & 13.09318 & 100 \\
\hline
\end{tabular}

Based on Table 2, it was revealed that a significant difference was found between the means of the control and experimental groups in the pre-test. The purpose was to find out that the treatment (role-play and simulation approach) had produced any significant differences in the performance of the subjects. The results showed that there was a significant difference between the pre-test and the post-test scores of the role-play and simulation group compared to the traditional group. Therefore, it can be concluded that there was a significant difference among the groups. The findings indicated that the students in the role-play and simulation group had performed better in the post-test compared to the pre-test after the exposure to the role-play and simulation approach in the ESL oral communication skills classes.

\section{Discussion}

\subsection{Research Question 1}

The following discussion is presented to address the first research question in the study.

What is the effect of role-play and simulation approach on Malaysian Polytechnic engineering students' ESL oral communication skills? 
The objective of the study was to investigate the effect of role-play and simulation approach on Malaysian Polytechnic engineering students' ESL oral communication skills. The NCA Speech Evaluation Form and Oral Presentation Rubrics adapted in this study were used to rate oral performance among Malaysian polytechnic engineering students. The result of the first question revealed that role-play and simulation can help students to enhance their oral communication skills. According to Fung and Min (2016), lack of communication skills is one of the reasons why employers are reluctant to hire job applicants. One of the difficulties which prevent learners from learning to speak in English is due to apprehension. This approach has become a teaching technique which encourages students to learn a new language in a creative and effective way. This technique allows them to react and communicate spontaneously and it really builds up their confidence level.

The result of the first research question revealed that role-play and simulation approaches have positive effect on enhancing ESL oral communication skills and help them especially to face the future career. The outcomes of this study match up with the findings of earlier researchers (Shankar et al., 2012), which reveal that this technique can expose students to different situations they are likely to face in their future career. From this approach, the students have a chance to explore different situations of real life that enable them to speak confidently and fluently in their second language. Additionally, implementing effective approach which focuses on improving students' pronunciation may help alleviate their fear of being unable to pronounce unfamiliar words.

\subsection{Research question 2}

The following discussion is presented to address the second research question in the study.

What are the students' perceptions towards the use of the role-play and simulation approach on their oral communication skills?

The objective of the study was to examine the students' perceptions towards the use of the role-play and simulation approach on their oral communication skills. The engineering students stated that this technique really helps them to develop oral communication skills. These findings supported the study conducted by Afdillah (2015), which stated that the use of role-play activities develops communication skills and students are encouraged to master through conversational activities. Besides that, these students also stated that role play engaged as a training approach that has the capacity to change behaviours and use only the best practices in the real world settings (Qing, 2011; Raja Hazirah Raja Sulaiman et al., 2017; Shangeetha \& Rajah Kumaran, 2017).

Besides that, the engineering students stated that they need to use role play and simulation approach in overcoming public speaking anxiety. This result is in line with P'Rayan and Shetty' (2008) study, revealing that students need more exposure and practice in overcoming their communication apprehension (P'Rayan \& Shetty, 2008). Lastly, the engineering students stated that this approach is interesting in real life situations. These findings supported the study conducted by Qing (2011) stated that role-play is defined as the projection in real life situations with social activities. These findings supported the study conducted by Krebt (2017) which stated that role play is to participate in simulated social situations that are intended to illustrate the roles and contexts that direct to the real life.

\subsection{Research question 3}

The following discussion is presented to address the third research question in the study.

What are the benefits of using role-play and simulation to the students in enhancing their ESL oral communication skills?

The study revealed that role-play and simulation have good benefits to the students in enhancing their ESL oral communication skills. The role-play and simulation activity helped learners to build their creativity. This finding supported by the study conducted by Altuan (2015) which stated that role-play is a strategy in which students are required to act specific roles through saying, doing, and sharing. Furthermore, using fun speaking activities, such as role-play and simulation approach really encourage the students to speak, and thus, this could lower their anxiety levels.

According to the results, the participants in the experimental group achieved better than those in the control group. Role-play and simulation are good activities because they helped learners to overcome the feeling of nervousness. A research conducted by Russell and Shepherd (2010) stated that role-play and simulation are forms of experiential learning. This finding proved that this technique induces learners to speak expressively in a situation, and thus makes 
them more aware of stress and intonation in speech. In other words, through the results derived from the study, roleplay and simulation, recommended by many experts in the field, were practically shown to be an effective and successful activity to be used in English lessons among Malaysian Polytechnic students.

\section{Conclusion}

The study revealed that role-play and simulation approach have positive effects on enhancing ESL oral communication skills among Malaysian Polytechnic engineering students. This paper has provided the insights as to how role play, a fun learning approach, is able to be a more dynamic and up-to-date learning approach on enhancing ESL oral communication skills. The researcher finally recommends that in order to cope with oral communication apprehension, learning situations and context, efforts should be made to make the ESL learning context less stressful. The ESL classroom should not be a place causing a lot of uneasiness and anxiety. Real life tasks such as role plays, dramas, and simulations could be adapted in the classroom so that students may have access to cultivate their competence up in various situations and cope with multifarious oral communication situations. Finally, another way of getting a more in-depth view of the issue could be to focus on the elementary school level, the formative, early years of education when students are still seeking their own communication identity. How the differences influence the development of spoken English skills, are some of the foundational questions that could be answered.

\section{References}

Abu Zahra, N. A., \& Farrah, M. A. (2016). Using Short Stories in the EFL Classroom. IUG Journal of Humanities Research, 24(1), 11-24.

Afdillah, N. M. (2015). The Effectiveness Of Role Play in Teaching Speaking. Master dissertation, Department of English Education, Faculty of Tarbiyah and Teachers' Training, Hidayatullah State Islamic University, Jakarta. http://repository.uinjkt.ac.id/dspace/handle/123456789/26710

Altun, M. (2015). Using Role-Play Activities to Develop Speaking Skills: A Case Study in the Language Classroom. Paper given at a conference, held on April 26-27, 2015 in Ishik University, Erbil, Iraq, In Book of Proceedings. p. 354.

Christopher, A. A. (2016). Overcoming impediments to learning the four language skills using note books. Advances in Language and Literary Studies, 7(1), 161-167. doi:10.7575/aiac.alls.v.7n.1p.161.

Fung, Y. M., \& Min, Y. L. (2016). Effects of board game on speaking ability of low-proficiency ESL learners. International Journal of Applied Linguistics \& English Literature, 5(3), 261-271. doi:10.7575/aiac.ijalel.v.5n.3p.261.

Karim, H. A. (2016). Unemployed because they can't speak English. The New Straits Times Online, p. 1-7. Shah Alam. http://www.nst.com.my/news/2016/02/125529/unemployed-because-they-cant-speak-english.

Keyton, J. (2011). Communication and organizational culture: A key to under-standing work experience. Thousand Oaks, CA: Sage.

Krebt, D. M. (2017). The Effectiveness of Role Play Techniques in Teaching Speaking for EFL College Learners. Journal of Language Teaching and Research, 8(5), 863-870. doi: http://dx.doi.org/10.17507/jltr.0805.04

Lee, H. L. J. (2016). SMAR Ties: Using a board game in the English classroom for edutainment and assessment. Malaysian Journal of ELT Research, $\quad 8(1), \quad 1-35$. https://journals.melta.org.my/index.php/majer/article/view/152

Littlewood, W. (2007). Communicative and task based language teaching in East Asian classrooms. Language Teaching, 40(3), 243-249. https://doi.org/10.1017/S0261444807004363

Mahdi, D. A. (2014). Willingness to communicate in English: A case study of EFL students at King Khalid University. English Language Teaching, 7(7), 17-25. doi: 10.5539/elt.v7n7p17 URL: http://dx.doi.org/10.5539/elt.v7n7p17

Mahdi, D. A. (2015). Strategies and techniques for fostering oral communication confidence in EFL students. Arab World English Journal, 6(2), 162-173. doi: 10.2139/ssrn.2834387 
Maier, H. W. (2002). Role playing: structures and educational objectives. CYC-online, eJournal of the International Child and Youth Care Network (CYC-Net), 36. www.cyc-net.org/cyconline/cycol-0102-roleplay.html.

Mustapha W. Z. W., Ismail, N., Singh, D. S. R., \& Elias S. (2010). ESL students' communication apprehension and their choice of communicative activities. Asean Journal of Teaching and Learning in Higher Education (AJTLHE), 2(1), 22-29. ejournal.ukm.my/ajtlhe/article/view/10488

P'Rayan, A., \& Shetty, R. T. (2008). Developing engineering students' communication skills by reducing their communication apprehension. English for Specific Purposes World, 7(4), 1-24. Www.espworld.info/Articles.../Communication\%20Apprehension\%20ESPworld.pdf

Qing, X. (2011). Role-play an effective approach to developing overall communicative competence. Cross-Cultural Communication, 7(4), 36-39. cscanada.net/index.php/ccc/article/download/j.ccc.1923670020110704.317/2177

Rahman, N. A., \& Maarof, N. B. (2015). The effects of communicative activities in reducing engineering students' communication apprehension in Polytechnic. 2015 Innovation \& Commercialization of Medical Electronic Technology Conference (ICMET), 87-93. doi: 10.1109/ICMETC.2015.7449579

Rao, D., \& Stupans, I. (2012). Exploring the potential of role-play in higher education: Development of a Typology and teacher guidelines. Innovations in Education and Teaching International, 49(4), 427-436. doi: $\underline{10.1080 / 14703297.2012 .728879}$

Russell, C., \& Shepherd, J. (2010). Online role-play environments for higher education. British Journal of Educational Technology, 41(6), 992-1002. https://doi.org/10.1111/j.1467-8535.2009.01048.x

Shangeetha, K. R. (2017). Benefits and shortcomings of role-play as a speaking activity in English language classrooms. The English Teacher. XXXIX, 72-93. https://journals.melta.org.my/index.php/tet/article/view/273

Shankar, P. R., Piryani, R. M., Singh, K. K., \& Karki, B. M. S. (2012). Student feedback about the use of role plays in Sparshanam. a medical humanities module [version 1; referees: 2 approved]. F1000Research 2012, 1:65 (doi: 10.12688/f1000research.1-65.v1)

Sulaiman, R. H. R., Din, N. M. N., Awang, R. E. N., Mustafa, Z., Noruddin, N., \& Talib, M. T. (2017). Role-Playing Technique in Teaching Arabic Communication: A Case Study at Universiti Sultan Zainal Abidin in Malaysia, International Journal of Academic Research, 309-318. https://ideas.repec.org/a/hur/ijarbs/v7y2017i10p309-318.html

Toledo, F., \& Hoit, S. (2016). Developing speaking skills in first grade: The impact of puppets on young learners' spoken interactions and motivation. Cambridge University Press Teacher Research Programme.

Yunus, N. M., \& Kaur, K. (2014). The use of indirect strategies in speaking: Scanning the MDAB students. ProcediaSocial and Behavioural Sciences, 123(1), 204-214. https://doi.org/10.1016/j.sbspro.2014.01.1416 